\title{
Development of Integrated Distribution and Inventory System Simulation Model Using Mobile Depot
}

\author{
Noveicalistus H. Djanggu \\ Department of Industrial Engineering, Universitas Tanjungpura, Indonesia \\ Corresponding Email: ${ }^{*}$ noveicalistus.djanggu@industrial.untan.ac.id
}

\begin{abstract}
Distribution activities are carried out to move an item from one point to another. Product distribution activities are conducted from the production area to the distribution or warehouse area, then from the warehouse to the retailer or consumer. Distribution activities can be established using various modes of land, river, ocean, and air transportation. Land transportation is greatly influenced by road conditions. River and sea transportation excels in carrying capacity which leads to the reduction of distribution costs. The disadvantages of water transportation are longer moving duration and dependence on weather. A warehouse is a typical facility used to accommodate inventory. Inventory system will generate holding costs. River transportation with a large carrying capacity can be used as a distribution medium and temporary warehouse. The land route in the West Kalimantan region is suitable for trucks with a moderate carrying capacity. River routes in West Kalimantan can reach several strategic areas, and river conditions have appropriate specifications for transportation mode with large capacities. The distribution and inventory system integration model using a mobile depot has been proposed in previous studies. Therefore, this research focuses on developing a simulation model for the aforementioned system. The results of this study are expected to provide information about the optimal value of the model configuration and strategy.
\end{abstract}

Keywords: distribution, inventory, mobile depot, simulation

\section{INTRODUCTION}

Distribution activities are conducted to move an item from one point to another. In general, they are carried out from the production area to the distribution or warehouse area, then from the warehouse to the retailer or consumer. Distribution activities can be carried out using various modes of land, river, ocean, and air transportation. Land transportation is very dependent on the road conditions. Good road conditions will speed up time and cost efficiency. River and sea transportations excel in carrying capacity. River transportation (inland waterway) has several advantages such as cheaper, safer and less polluting when compared to the other modes of transportation [7]. Large transport capacity will reduce distribution costs. Disadvantages of river and sea transportation are slower moving time and dependence on weather. The network integration of road and river routes can form a distribution network [4].

Inventory is employed to fulfill consumer demand. A warehouse is a facility commonly used to accommodate inventory. The inventory system will generate storage costs. Good management of the inventory system is required in order to produce efficient storage costs. In this study, the river transportation mode with a large capacity will have a dual function as a distribution mode and a stock warehouse. Intermodal system is a distribution system involving more than one type of transportation mode. An intermodal system between river transportation, such as Bandong or Tongkang boat, and land transportation modes, such as truck, will be implemented to support an integrated distribution and inventory system.

West Kalimantan has a land topology that is divided by a river path. The land route in West Kalimantan is suitable for trucks with a medium carrying capacity [7]. River routes in West Kalimantan can reach several strategic areas, and the river condition possesses proper specifications for transportation modes with large capacities. The integration of distribution and inventory systems using mobile depots will then increase the level of complexity in the decision making of each entity involved. The probability level of several variables will increase the complexity of the system. The simulation model developed in this study will be used to accommodate the complexity of the system [3]. Decisions resulting from the simulation model are expected to provide information that can be used to take strategic steps in optimizing the system.

\section{METHODOLOGY}

The simulation model in this study is applied to accommodate the adjustment of the observed system. Conceptual modeling is carried out to identify the entities involved in the proposed simulation model. Determination of intermediate variables, constants, and decision variables are based on the reference model. The collection and use of real data in the simulation model become a significant input value in determining the optimal configuration and strategy of this research.

The simulation model is developed based on the conceptual model using real data from the observations. The simulation model is run after it passes the verification and validation stages. The results of running the simulation model will subsequently be evaluated based on the established criteria and adjusted to the integration strategy to achieve the ideal performance indicator [3]. Figure 1 is the illustration of the research flow chart. 


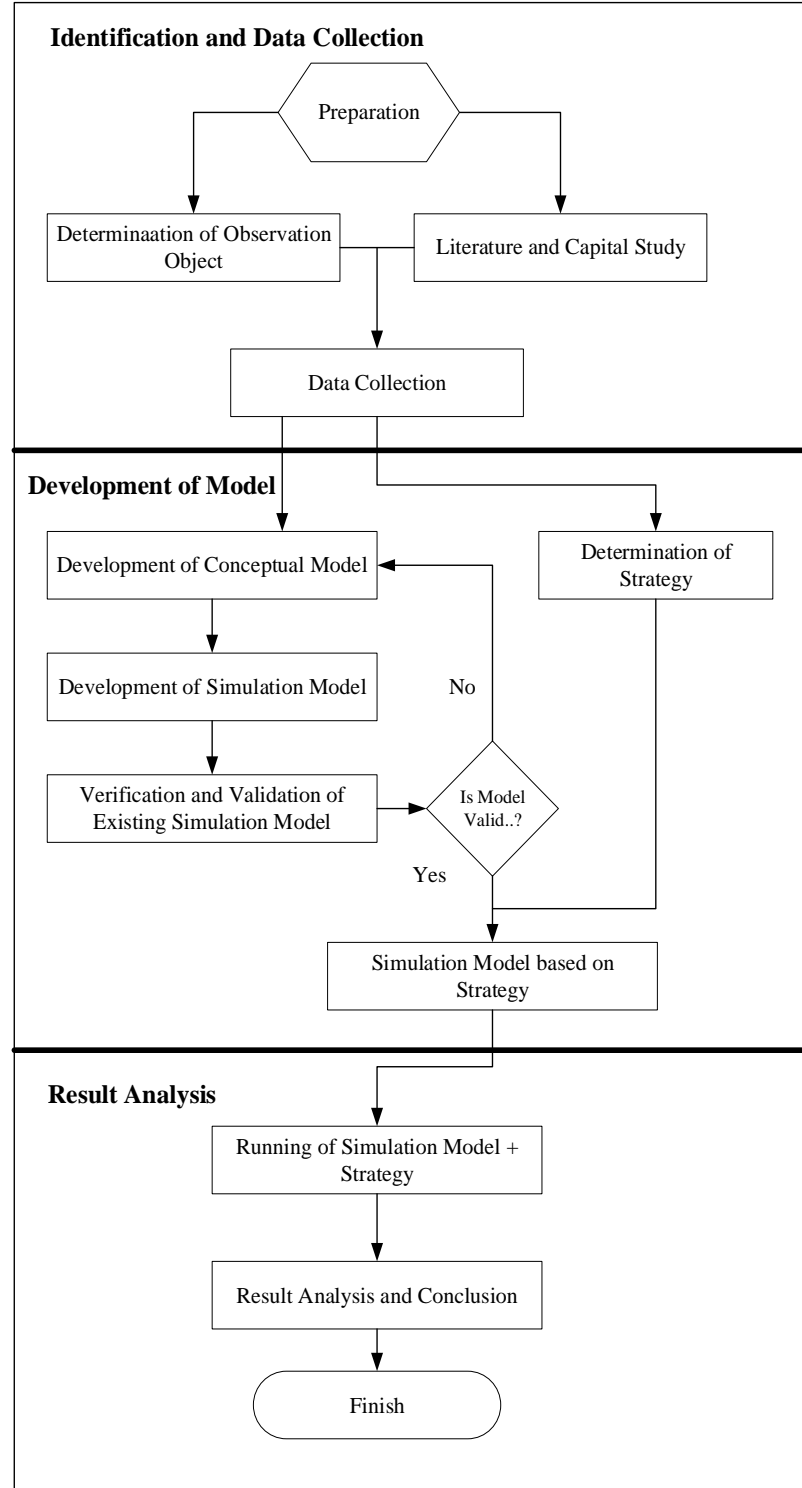

Figure 1. Flowchart

\section{RESUlt AND DiscUSSION}

This study seeks to obtain a simulation model of mobile warehouse planning. Warehouse is represented by Bandong as a means of transportation. The concept of a mobile warehouse is integrated with trucks as a land transportation mode. Bandong with a large carrying capacity moves using river routes from one point to another. When Bandong reaches a certain point, the goods are unloaded and transferred to trucks for distribution to the destination.

\subsection{Distribution Using Bandong}

Distribution using Bandong passes through several regencies crossed by the Kapuas River, they are Sanggau, Sekadau, Sintang and Putussibau. However, in this study, only 3 districts were used as points of demand, i.e., Sanggau, Sekadau, and Sintang.

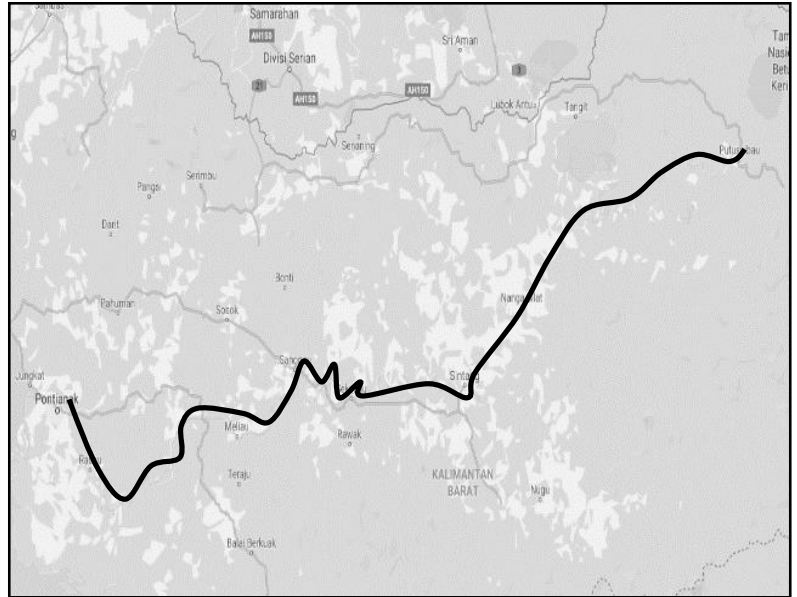

Figure 2. Bandong Distribution Line

\subsection{Distribution Using Truck}

Distribution using trucks is divided based on each district that has been traversed by Bandong. The following are the distribution routes of truck based on the existing districts:

1. Sanggau Regency

There are 4 districts in Sanggau Regency traversed by Bandong, i.e., Kapuas, Meliau, Parindu, and Tayan Hilir.

2. Sekadau Regency

There are 4 districts in Sekadau Regency traversed by Bandong, i.e., Belitang Hulu, Nanga Taman, Sekadau Hilir, and Sekadau Hulu.

3. Sintang Regency

There are 4 districts in Sintang Regency traversed by Bandong, i.e., Ambalau, Kayan Hilir, Serawai, and Sepauk.

\subsection{Data Collection on Demand}

Collection of demand data is conducted using random data for each region. This random data is also based on which area is wide and has a large population. Only several areas are considered in this research.

Table 1. Data of Regional Demand

\begin{tabular}{llcc}
\hline Regency & District & Total & Safety Stock \\
\hline \multirow{5}{*}{ Sanggau } & Sanggau & 20 & \\
& Kapuas & 14 & 24 \\
& Meliau & 11 & \\
& Parindu & 19 & \\
& TayanHilir & 12 & \\
\hline \multirow{5}{*}{ Sekadau } & Sekadau & 18 & \\
& Belitang Hulu & 16 & \\
& Nanga Taman & 15 & 8 \\
& Sekadau Hilir & 8 & \\
& Sekadau Hulu & 14 & \\
Sintang & Sintang & 19 & \\
& Ambalau & 14 & \\
& Kayan Hilir & 10 & 16 \\
& Serawai & 16 & \\
& Sepauk & 12 & \\
\hline
\end{tabular}




\subsection{Data Collection on Regional Distance}

Collection of regional distance data is conducted both between regencies and between districts. The distance between regencies is the distance travelled by Bandong to carry goods. The inter-district roads are used by trucks to distribute goods carried by Bandong to the destination point. Distance data, obtained through secondary data retrieval from Google Maps, is divided into 2, i.e., the distance between regencies via the Kapuas River and the distance between districts by land. Table 3 summarizes the distance between regencies and Table 4 to Table 6 highlight the distance between districts.

Table 2. Distance between Regencies

\begin{tabular}{cccccc}
\hline & Pontianak & Sanggau & Sekadau & Sintang & Putussibau \\
\hline Pontianak & 0 & 211 & 297 & 416 & 719 \\
\hline Sanggau & 211 & 0 & 86 & 119 & 303 \\
\hline Sekadau & 297 & 86 & 0 & 33 & 184 \\
\hline Sintang & 416 & 119 & 33 & 0 & 151 \\
\hline Putussibau & 719 & 303 & 184 & 151 & 0 \\
\hline
\end{tabular}

Table 3. Distance between Districts in Sanggau

\begin{tabular}{cccccc}
\hline & Sanggau & Kapuas & Meliau & Parindu & Tayan Hilir \\
\hline Sanggau & 0 & 24 & 154 & 30 & 88 \\
\hline Kapuas & 24 & 0 & 163 & 39 & 97 \\
\hline Meliau & 154 & 163 & 0 & 138 & 66 \\
\hline Parindu & 30 & 39 & 138 & 0 & 88 \\
\hline $\begin{array}{c}\text { Tayan } \\
\text { Hilir }\end{array}$ & 88 & 97 & 66 & 88 & 0 \\
\hline
\end{tabular}

Table 4. Distance between Districts in Sekadau

\begin{tabular}{cccccc}
\hline & Sekadau & $\begin{array}{c}\text { Belitang } \\
\text { Hulu }\end{array}$ & $\begin{array}{c}\text { Nanga } \\
\text { Taman }\end{array}$ & $\begin{array}{c}\text { Sekadau } \\
\text { Hilir }\end{array}$ & $\begin{array}{c}\text { Sekadau } \\
\text { Hulu }\end{array}$ \\
\hline Sekadau & 0 & 134 & 43 & 82 & 29 \\
\hline $\begin{array}{c}\text { Belitang } \\
\text { Hulu }\end{array}$ & 134 & 0 & 169 & 115 & 154 \\
\hline $\begin{array}{c}\text { Nanga } \\
\text { Taman }\end{array}$ & 43 & 169 & 0 & 117 & 33 \\
\hline $\begin{array}{c}\text { Sekadau } \\
\text { Hilir }\end{array}$ & 82 & 115 & 117 & 0 & 102 \\
\hline $\begin{array}{c}\text { Sekadau } \\
\text { Hulu }\end{array}$ & 29 & 154 & 33 & 102 & 0 \\
\hline
\end{tabular}

Table 5. Distance between Districts in Sintang

\begin{tabular}{cccccc}
\hline & Sintang & Ambalau & $\begin{array}{c}\text { Kayan } \\
\text { Hilir }\end{array}$ & Serawai & Sepauk \\
\hline Sintang & 0 & 44 & 92 & 28 & 180 \\
\hline Ambalau & 44 & 0 & 141 & 80 & 228 \\
\hline Kayan Hilir & 92 & 141 & 0 & 86 & 90 \\
\hline Serawai & 28 & 80 & 86 & 0 & 156 \\
\hline Sepauk & 180 & 228 & 90 & 156 & 0 \\
\hline
\end{tabular}

\subsection{Simulation Model of Distribution Using Bandong}

Figure 2 shows a conceptual model of a distribution network by using Bandong. The Bandong trip starts from Pontianak as the depot. Figure 3 is a flowchart of Bandong conceptual model. First, the Bandong will wait for the goods in Pontianak, if it is ready then the goods will be loaded into Bandong until it is full or no goods are available. Then Bandong departs to the destination. After finishing at one destination, it is checked whether there are still other destinations to be visited. If there is, the goods are checked for the availability. If the goods and destinations are available, Bandong will then proceed to the next destination. Otherwise, it will immediately return to the original depot in Pontianak. Figure 3 depicts the flowchart of Bandong conceptual model.

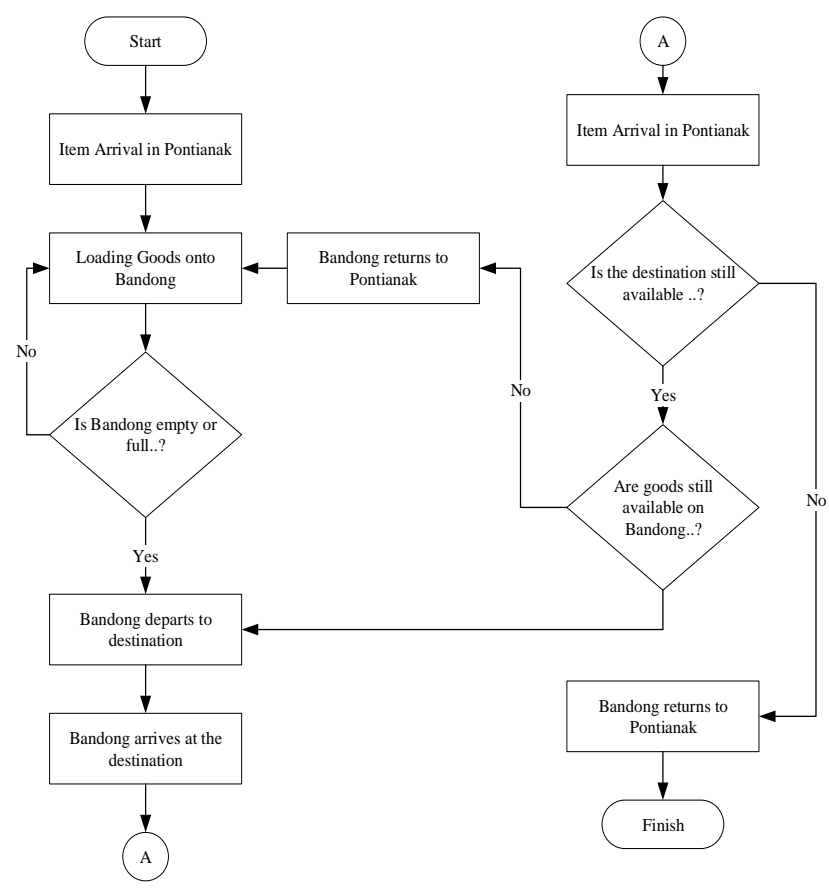

Figure 3. Flowchart of Bandong Conceptual Model

\subsection{Simulation Model of Distribution Using Truck}

The truck trip starts from Pontianak as the starting point. First, the truck leaves for the first location from Pontianak. When it arrives, the availability of safety stock in the area is checked. If it is available, the goods will be loaded directly into the truck. If it is no longer available, the truck will wait for the goods carried by Bandong to arrive at the dock. If the goods from the dock are available, then loading of the goods proceeds and then the truck leaves for the next location. After arriving and finishing unloading goods based on demand, the truck continues its trip to the next location, if there are still any destination and goods available. If no goods are available and there are still destinations to visit, then the truck returns to the initial location in the regency. However, if there are no more locations to visit and no available goods, then the truck proceeds to the next regency and carries out the tasks as in the previous location. When all routes have been finished, the truck travels back to Pontianak. Figure 4 below is a conceptual model flowchart of a truck. 


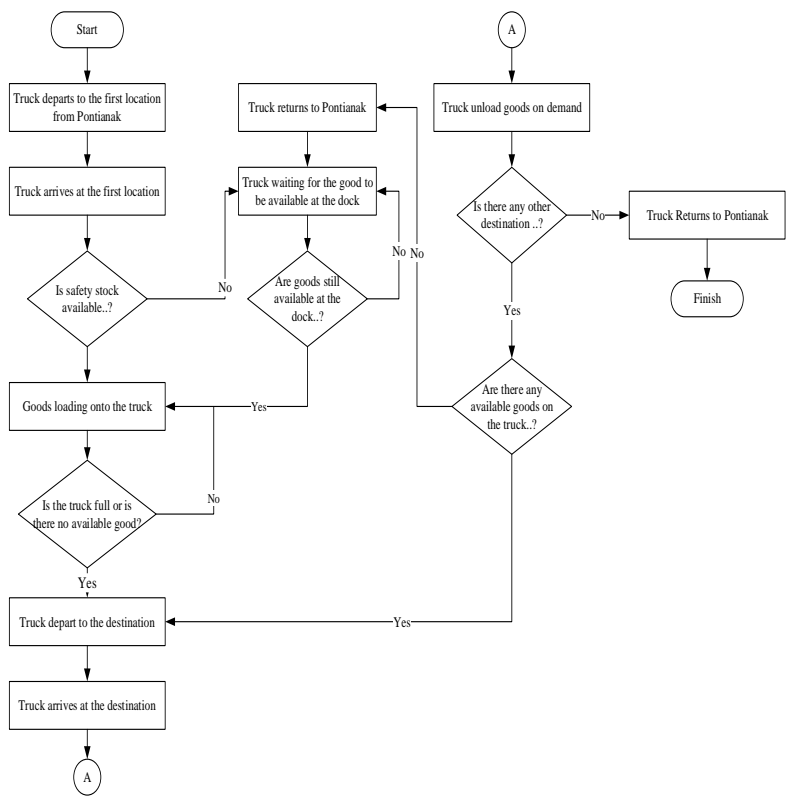

Figure 4. Flowchart of Truck Conceptual Model

\subsection{Simulation Model of Distribution Network}

The simulation model is built based on a conceptual model which represents the observed real system. The simulation model in this study uses 7 principles, i.e., Create, Assign, Hold, Station, Route, Decide, and Dispose [5].

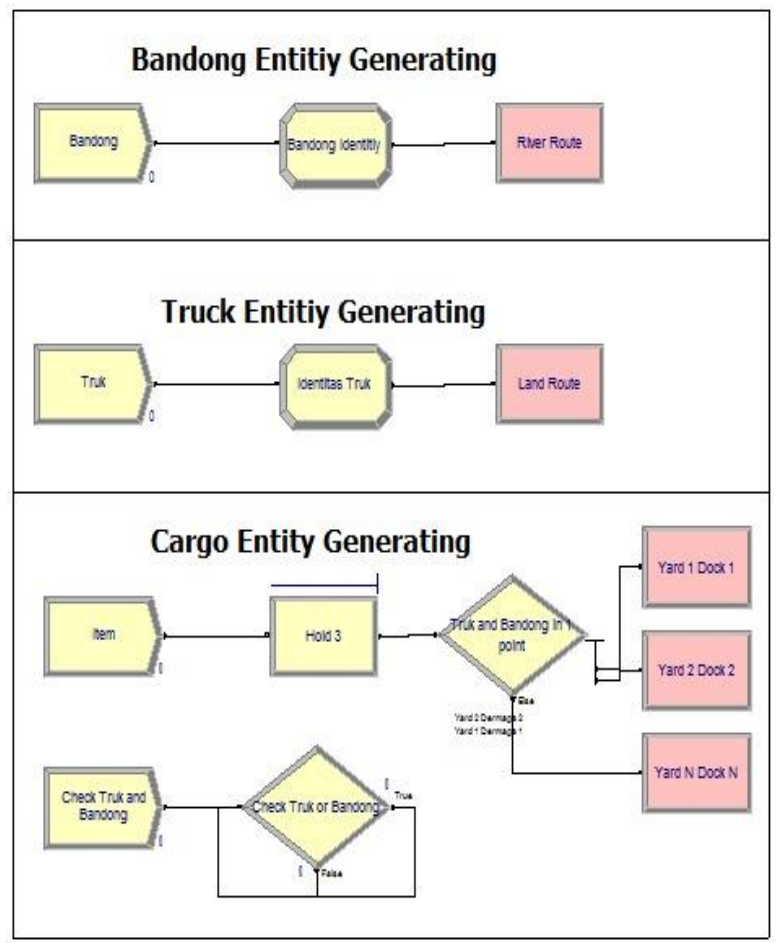

Figure 5. Entity Generation Model of Bandong, Truck, Load, and Distribution Route

The proposed conceptual model that is built is then transformed into a simulation model [9]. Figure 5 represents the logic to generate the three entities involved in the moving Bandong model, they are Bandong, trucks, and goods [9]. Bandong and truck distribution lines are generated in the simulation model. Bandong will travel through the river, truck will take the truck distribution route.

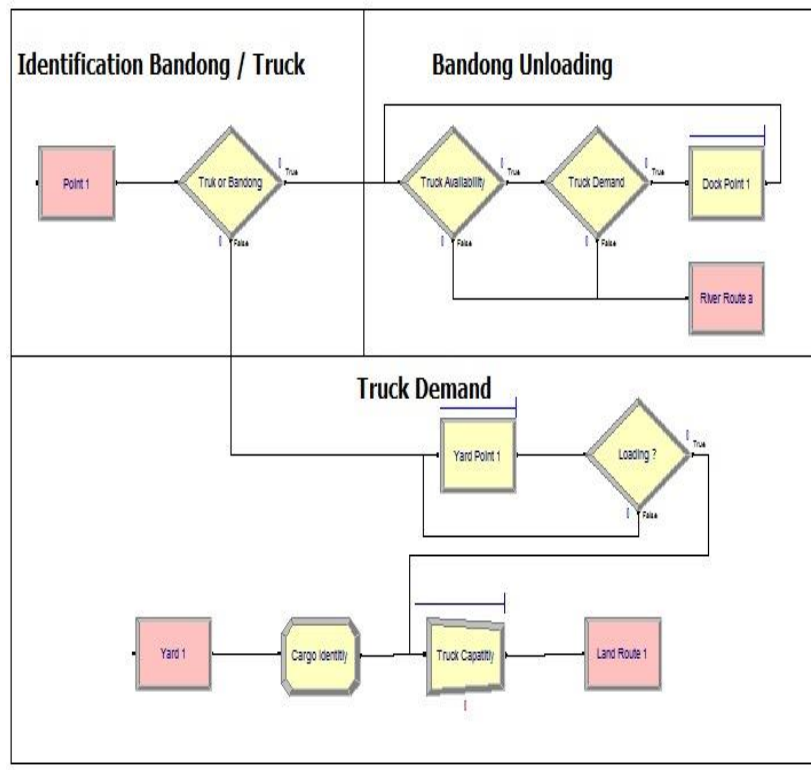

Figure 6. Model of Bandong Unloading and Truck Demand

Figure 6 describes the proposed logic to carry out the goods loading and unloading from Bandong onto trucks at the destination point in each regency. Bandong carries the maximum amount of goods according to its capacity. After arriving at the destination point, the goods will be unloaded and loaded onto the truck as requested. Loading and unloading activities from Bandong onto truck are carried out at the dockyard in each regency. Bandong will stop unloading goods when the truck does not request any. The loaded truck will go to the destination district to carry out loading and unloading on demand in each district. The truck will conduct the loading process at the dockyard in the district if there is still demand from other destinations. If all requests have been fulfilled, the truck will stop loading goods at the dockyard.

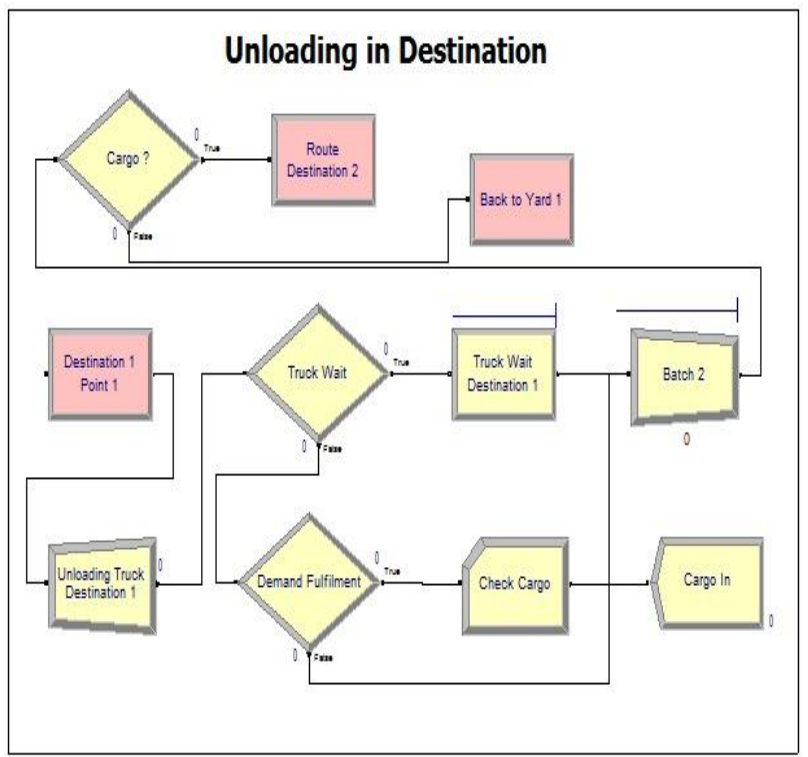

Figure 7. Model of Truck Unloading at Destinations 
Figure 7 is the logic of simulation model built to carry out the truck unloading function in the destination district. After arriving at the destination point, the truck unloads the goods. If the demand has not been fulfilled, the truck will return to the dock to receive goods from Bandong. After the truck is loaded at the district destination point, it will proceed to the next district to fulfill the demand.

\subsection{Model Verification}

The verification process is carried out to measure whether the simulation model built is relevant with the conceptual model. Verification is done by testing the logic flow built on the simulation model based on the conceptual model [7]. The flow of the developed simulation model has been adjusted to the previous conceptual model; thus, it can be stated that the model has been verified. The next step is carrying out a validation process, however, it cannot be conducted as there is no real existing condition for this problem. In the moving Bandong simulation model, the validation process is not carried out because there is no existing system that can be compared.

\subsection{Result Analysis of Simulation Model Running}

The simulation model is then run using the existing data. The simulation model in this study is carried out by developing two scenarios. The first scenario is based on the shortest distance, in this scenario, Bandong and truck will move from one point to another based on the closest one. If the first closest distance is successfully covered, Bandong or truck will depart to the next closest one. The second scenario is based on the highest demand. Bandong and truck will move from one point to another based on the most demand regardless of the distance. If the highest demand has been met, Bandong or truck will leave for the next destination with the most demand. The number configuration of Bandong and truck is one unit, respectively, for each scenario. The performance indicator of each scenario is the amount of travel time. From the result comparison of the time required to complete one distribution cycle, it is found that the model of the closest distance scenario achieves the shortest duration (77.1 hours). The highest demand scenario requires a distribution time of 307.9 hours. After running the two models, then the simulation is proceeded using a combination of ratio and the number of trucks as scenarios.

Table 6. Result of Distribution Time

\begin{tabular}{llccc}
\hline No & Model & $\begin{array}{c}\text { Number } \\
\text { of } \\
\text { Bandong }\end{array}$ & $\begin{array}{c}\text { Number } \\
\text { of } \\
\text { Truck }\end{array}$ & $\begin{array}{c}\text { Duration } \\
\text { (Hours) }\end{array}$ \\
\hline 1. & Jarak Terdekat & 1 & 1 & 77,1 \\
\hline 2. & $\begin{array}{l}\text { Demand } \\
\text { Terbanyak }\end{array}$ & 1 & 1 & 307,9 \\
\hline
\end{tabular}

\subsection{Result Analysis of Scenario Running}

Table 7 summarizes the result of running the simulation by combining the number of entity units. The maximum number of Bandong used is 2 units and the maximum unit of trucks used are 3 units. The combination of simulations is carried out by using various configurations in two scenarios, i.e., the shortest distance and the highest demand. The purpose of running simulations using various configurations is to find out the results that can be obtained from the mobile depot model. The results show that the configuration of the highest number of units provides a shorter distribution time for each scenario.

Table 7. Result of Scenario Running

\begin{tabular}{|c|c|c|c|c|}
\hline \multirow{2}{*}{ No } & \multirow{2}{*}{ Model } & \multicolumn{2}{|c|}{ SCENARIO } & \multirow{2}{*}{$\begin{array}{c}\text { Duration } \\
\text { (Hours) }\end{array}$} \\
\hline & & $\begin{array}{c}\text { Number of } \\
\text { Bandong }\end{array}$ & $\begin{array}{l}\text { Number } \\
\text { of Truck }\end{array}$ & \\
\hline 1 & \multirow{6}{*}{$\begin{array}{l}\text { Shortest } \\
\text { Distance }\end{array}$} & 1 & 1 & 77.1 \\
\hline 2 & & 1 & 2 & 69.7 \\
\hline 3 & & 1 & 3 & 62.5 \\
\hline 4 & & 2 & 1 & 65.5 \\
\hline 5 & & 2 & 2 & 49.3 \\
\hline 6 & & 2 & 3 & 39.9 \\
\hline 7 & \multirow{6}{*}{$\begin{array}{l}\text { Highest } \\
\text { Demand }\end{array}$} & 1 & 1 & 307.9 \\
\hline 8 & & 1 & 2 & 298.4 \\
\hline 9 & & 1 & 3 & 289.8 \\
\hline 10 & & 2 & 1 & 253.2 \\
\hline 11 & & 2 & 2 & 236.1 \\
\hline 12 & & 2 & 3 & 223.7 \\
\hline
\end{tabular}

\section{CONCLUSION}

This study focuses on managing the distribution of goods using the concept of a mobile warehouse, which in this case is represented by Bandong. Trucks are used as a means of distributing goods on land. This research is able to produce a distribution system simulation model using movable Bandong with two scenarios. The first scenario, by using the order of distribution based on the closest distance, results in a distribution time of 77.1 hours. The second scenario, by using the order of highest demand, results in a distribution time of 307.9 hours. Thus, the simulation result for the shortest distance scenario provides a shorter distribution time performance than the other one. The configuration of the highest number of transportation units provides a better performance for the shortest distance and the highest demand scenarios.

\section{REFERENCES}

[1] Crainic, T.G., Perboli .G., Rosano. M.”Simulation of intermodal freight transportation systems: a taxonomy,"European Journal of Operational Research, 2017.

[2] Jiang,Y., Lu J., Cai Y., \& Zeng Q.,"Analysis of The Impact of Different Modes of Governance on Inland Waterways Transport Development on The Pearl River : The Yangtze River Mode vs the Pearl River Mode", Journal of Transport Geography, 2017. 
[3] Kelton, David, R. Sadowski."Simulation With Arena $3^{\text {rd }}$ Edition,'WCB McGraw-Hill,2000.

[4] Newman,M.E.J. (2003).'The Structure and Function of Complex Networks", Physical Review, vol 45,no. 2, pp.58,2003.

[5] Reggiani, A., Signoretti, S., Nijkamp, P., \& Alessandro, C."Network Measures in Civil Air Transport: A Case Study of Lufthansa,'In Networks, Topology and Dynamics, pp. 257-282, 2009.

[6] Sihn,W., Pascher,H., Ott,P.,Stein,S.,Schumancher,A., \& Mascolo,G.,"A Green and Econmic Future of Inland Waterways Shipping", in Procedia CIRP 29, pp.217 322,2015 .

[7] Sofitra, M., H. Djanggu, N., Wijayanto, D., Anggela, P., Fikri, M., \& Ribuwansyah. "Sistem logistik sungai dan laut di wilayah pesisir studi kasus: Kab. Kubu Raya dan Kab. Kayong Utara", In Prosiding Seminar Nasional Penerapan Ilmu Pengetahuan dan Teknologi 2017,2017.

[8] Wang, J., Mo, H., Wang, F., \& Jin, F.'Exploring the network structure and nodal centrality of China' $\mathrm{s}$ air transport network: A complex network approach", Journal of Transport Geography, No.19, pp.712-721, 2011.

[9] Wiegmans,B., \& Konings,R.,'Intermodal Inland Waterway Transport : Modelling Conditions Influencing It's Cost Competitiveness", European Journal of Shipping and Logistics,2015. 